\title{
The effects of aqueous extract of babassu (Orbignya phalerata) on the pleura and lung parenchyma in rats ${ }^{1}$
}

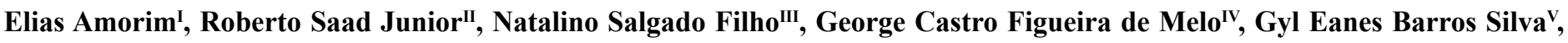 \\ Rennan Abud Pinheiro Santos ${ }^{\mathrm{VI}}$, Danilo Dallago de Marchi ${ }^{\mathrm{VI}}$, Ricardo Comunello de Carli ${ }^{\mathrm{VI}}$, Osvaldo Malafaia ${ }^{\mathrm{VII}}$, Jurandir \\ Ribas-Filho $^{\text {VIII }}$
}

DOI: http://dx.doi.org/10.1590/S0102-865020160040000004

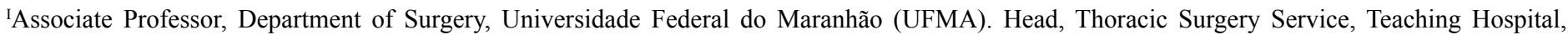
UFMA, Sao Luis-MA, Brazil. Intellectual, scientific content and design of the study; technical procedures; manuscript writing; supervised all phases. IIFull Professor, Hospital da Santa Casa de São Paulo. Head, Thoracic Surgery Service, Santa Casa de São Paulo, Brazil. Acquisition and interpretation of data, design of the study.

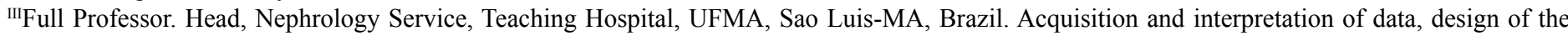
study.

IVPathologist, Teaching Hospital, UFMA, Sao Luis-MA, Brazil. Acquisition and interpretation of data, design of the study.

'Pathologist, Teaching Hospital, UFMA, Sao Luis-MA, Brazil. Technical procedures, critical revision, final approval the manuscript.

${ }^{\mathrm{VI} G r a d u a t e}$ student, School of Medicine, UFMA, Sao Luis-MA, Brazil. Technical procedures.

${ }^{\mathrm{VII}} \mathrm{Head}$, Postgraduate Program in Principles of Surgery, Faculdade Evangélica do Paraná (FEPAR), Curitiba-PR, Brazil. Critical revision, final approval the manuscript.

${ }^{\mathrm{VIII}}$ Coordinator, Postgraduate Program in Principles of Surgery, FEPAR, Curitiba-PR, Brazil. Critical revision, final approval the manuscript.
\end{abstract}

\begin{abstract}
PURPOSE: To evaluate macro and microscopically, changes following the use of the aqueous extract of babassu (Orbignya phalerata) in the lung parenchyma and pleura of rats.

METHODS: Sixty adult male rats with average weight of $350 \mathrm{~g}$, were randomized into two groups of 30 animals (experimental and control) further divided into sub-groups of 10 to be sacrificed at $48 \mathrm{~h}, 72 \mathrm{~h}$ and 21 days. The substance was injected into the right pleura of the animals.

RESULTS: There was intense pleuropulmonary macroscopic reaction with statistically significant differences between groups respectively ( $p<0.05, p<0.02, p<0.03$ ). Microscopically, no statistically significant difference was evident ( $>>0.05)$.

CONCLUSION: The aqueous extract of babassu (Orbignya phalerata) was found to be highly irritating to the pleura and lung of rats, evidenced macroscopically by numerous adhesions and inflammation while no major changes were evident microscopically.
\end{abstract}

Key words: Plants, Medicinal. Phytotherapy. Pleura. Lung. Rats. 


\section{Introduction}

Pleurodesis is a well-established treatment for patients with spontaneous pneumothorax or malignant pleural effusion of multiple causes. The objective of pleurodesis is to promote the symphysis of the parietal and visceral pleura by inducing fibrosis, with consequent obliteration of the pleural space, thereby preventing the accumulation of air and fluid in the pleural cavity ${ }^{1-5}$.

The ideal agent for pleurodesis has yet to be found. Several substances have been studied both clinically and experimentally, such as ethanolamine oleate, diazepam, erythromycin, macrolides, quinolones, povidone-iodine, in search of an agent with the following characteristics: effective, widely available, low cost, and few side effects ${ }^{6}$. Currently, the most commonly used agents are talc instilled into the pleural cavity by aspersion or dilution in saline solution, tetracycline derivatives (minocycline and doxycycline), and bleomycin ${ }^{7-10}$. In the 1980 s, tetracycline was the preferred agent for chemical pleurodesis. However, manufacture of tetracycline has ceased and is therefore no longer available for this application. Bleomycin is very high cost and less effective in the treatment of pleurodesis compared to other medications ${ }^{11}$.

Babassu represents an abundant, economically important plant. The mesocarp of the fruit is rich in carbohydrates and minerals and exhibits anti-inflammatory activity ${ }^{10}$. Various publications have reported the use of babassu in a variety of different situations. Its use in bladder healing in rats has shown a microscopically favorable effect ${ }^{11}$. Also in rats, a similarly positive effect was observed both macro- and microscopically in cutaneous wounds, with action most evident during the first healing phase ${ }^{12}$. When administered intraperitoneally at a dose of $50 \mathrm{mg} / \mathrm{kg}$ of bodyweight, full coaptation of the edges of gastric wounds ${ }^{13,14}$ and enhanced healing in the abdominal alba line were observed ${ }^{15}$.

Regarding pleuropulmonary changes, no studies are available investigating the use of babassu. Westphal FL et al., studying changes after injection of copaiba (Copaifera sp), observed major irritation in the rat's pleura ${ }^{16}$.

Pharmacological trials using the mesocarp of babassu have proven the potent anti-inflammatory action of powder extract in several experimental models of inflammation, confirming its action as a healing and anti-inflammatory agent $\mathrm{t}^{17}$.

The objective of this study was to verify if the aqueous extract of Orbignya phalerata can induce changes in the pleura and lung parenchyma of rats.

\section{Methods}

This study was carried out at the Central Animal House, Universidade Federal do Maranhão (UFMA). The study had an experimental, prospective, randomized design and was based on the following criteria: animals that are easy to breed and keep; low-cost and painless anesthesia technique; minimally invasive surgical approach; and requiring no special care postoperatively.

The experimental protocol of this study was approved by the Ethics Committee on Animal Use (CEUA 23115.017952/201301) of the Federal University of Maranhão.

During the operative procedure, the animals breathed spontaneously without use of respiratory support.

\section{Study design and animal handling}

In accordance with the established criteria, 60 Rattus norvegicus albinus, Rodentia mammalia, Wistar, male, adults, with an average weight of $350 \mathrm{~g}$ were selected. Animals were treated and housed in individual drawer-type cages of stainless steel wire mesh with hole size of $10 \mathrm{~mm}$, measuring $23 \times 20 \times 25$ $\mathrm{cm}$, the rear of which was protected by $10 \times 10 \mathrm{~mm}$ square mesh screen. The cage contained a stainless steel feeder and a $250 \mathrm{ml}$ polypropylene drinking vessel fitted with anti-acid rubber stopper and stainless steel drinking nipple. Cages were kept under a controlled environment with control of luminosity intensity and duration, temperature, ventilation, noise and odors with water and feed provided ad libitum. Animals were randomized into two groups of 30 as follows: control group (treated with $0.9 \%$ physiological saline solution) and babassu group (treated with pure aqueous extract). Each group was then divided into three subgroups of 10 animals, according to the pre-established timepoints for application of the substances, observation of the animals and histological analysis at $48 \mathrm{~h}, 72 \mathrm{~h}$ and 21 days.

\section{Preparation of extract and operative procedures}

For the preparation of the aqueous extract, the powder was weighed and diluted in distilled water to a concentration of $25 \mathrm{mg} /$ $\mathrm{ml}(10 \mathrm{~g} / 400 \mathrm{ml}$ distilled water) for the $50 \mathrm{mg} / \mathrm{kg}$ (concentration of $25 \mathrm{mg} / \mathrm{ml}$ ) dose used directly in the pleural space. Thus, a dose of $0.8 \mathrm{ml}$ of solution was administered for every $400 \mathrm{~g}$ of bodyweight of the animal.

The mesocarp of the coconuts was removed using a wooden club. The top of the coconuts were beaten by hand until 
rupture of the shells. The exposed material (mesocarp) was then removed with a spatula and placed on the bench top for three days to dry. When dried, the material was placed in a drying oven at a temperature of $45-50^{\circ} \mathrm{C}$ for 24 hours to complete the removal of moisture. The dried material was subjected to a grinding process in an electric mill at the Technological Pavilion Laboratory, UFMA, yielding a flour powder.

All procedures were performed under intramuscular anesthesia using $5 \%$ ketamine hydrochloride at $60 \mathrm{ml} / \mathrm{kg}$ of bodyweight in association with $2 \%$ xylazine hydrochloride at $10 \mathrm{mg} / \mathrm{kg}$ of bodyweight. The route of administration was via the posterior face of the thigh, preceded by local asepsis, in the subxiphoid region. At the site, hair was removed for $1 \mathrm{~cm}^{2}$ and the area disinfected with povidone-iodine. The product was injected trans-diaphragmatically into the right pleural cavity using a BD12F peridural anesthesia needle. For more rapid recovery and a lower level of suffering, stress and mortality, the rats were submitted to post-anesthetic oxygen therapy for approximately $10 \mathrm{~min}$ before being placed in their respective cages.

The animals were sacrificed at 48 hours, 72 hours and 21 days after injection of the selected substance.

Histopathological analysis was performed by an experienced pathologist, ensuring blinded assessment, under an optical microscope of $5 \mathrm{~mm}$-thick histological slices stained with H\&E. The histopathological variables were studied over the whole histological section.

The semiquantitative method was employed to analyze the intensity/degree of inflammatory reaction based on a score of 0 to 3. A score of 0 indicated the inflammatory response was "absent" (inflammation parameters undetected); 1 "mild" (inflammation parameters in up to $20 \%$ of sample); 2 "moderate" (inflammation parameters between $20 \%$ and $50 \%$ of sample); and 3 "severe" (inflammation parameters in over $50 \%$ of the sample). For grading, the presence of the following histopathological findings was considered: vascular congestion (blood flow increase/vasodilatation), edema ("negative image" pleural/ interstitial/alveolar wall) and inflammatory pleural/intra-alveolar/ interstitial/peribronchial cell infiltration (leukocytes mono and/or polymorphs).

\section{Macro and microscopic assessments}

The following parameters were adopted for the macroscopic analyses and classified as described by Tonietto et $a l{ }^{16}$ : grade $0=$ no macroscopic changes; grade $1=$ presence of exsudate, without fibrinous reaction and/or adhesions; grade $2=$ presence of exsudate, with mild fibrinous reaction and slight adhesions; grade 3=presence of exsudate, with moderate fibrinous reaction and moderate adhesions; grade $4=$ absence of exsudate, lung stuck by intense fibrinous reaction and numerous adhesions.

The following two classifications were used in the analysis of microscopic changes: one denoting the grade of inflammatory reaction and the other categorizing the type of reaction as acute or chronic. The neutrophilic infiltrate, interstitial edema and vascular congestion were the indicators of the acute inflammatory process. The presence of vascular proliferation, mononuclear cell infiltration, fibroblast proliferation, fibrosis (collagen deposition) were chronic process. The following grades were used to assess the reaction: grade $0=$ no microscopic change; grade $2=$ mild inflammatory reaction; grade $2=$ moderate inflammatory reaction; grade $3=$ severe inflammatory reaction.

\section{Statistical analysis}

The data were assessed using the statistics program IBM SPSS Statistics 20 (2011). Graphs and tables depicting the frequency of variables were first produced. Subsequently, the Chi-square $(\chi 2)$ test of independence was applied to assess the association of grade of reaction, type of reaction, pneumonitis and macroscopic analysis for the two groups (control and babassu). Non-parametric Mann-Whitney test was employed to assess the effect of babassu on each day and overall on the ordinal variables grade of reaction, reaction type and macroscopic analysis where the non-parametric Kruskall-Wallis and Student-Newman-Keuls post-hoc test for pair-wise comparisons were used to assess the time effect ( $48 \mathrm{~h}, 72 \mathrm{~h}$ and 21 days) within each group (control and babassu). A $5 \%$ level of significance $(\alpha)$ was adopted and considered significant for values of $\mathrm{p}<0.05$.

\section{Results}

The variables grade of reaction, type of reaction and pneumonitis showed no significant difference $(p>0.05)$ between groups. However, the groups differed significantly ( $<<0.05$, Table 1) on macroscopic analysis, with $73.3 \%$ of the babassu group exhibiting some degree of macroscopic change and $90 \%$ of the control group showing no changes (Table 2). 
TABLE 1 - Distribution according to grade and type of reaction, presence of pneumonitis and macroscopy by group.

\begin{tabular}{ccccccc}
\hline \multirow{2}{*}{ Variable } & Group & & \\
& Control & $\%$ & Babassu & $\%$ & Total & \\
\hline
\end{tabular}

\begin{tabular}{|c|c|c|c|c|c|c|}
\hline \multicolumn{7}{|c|}{ Grade of reaction } \\
\hline Grade 0 & 19 & 63.3 & 12 & 40.0 & 31 & \\
\hline Grade 1 & 11 & 36.7 & 15 & 50.0 & 26 & 0.074 \\
\hline Grade 2 & 0 & 0.0 & 3 & 10.0 & 3 & \\
\hline
\end{tabular}

Type of reaction

\begin{tabular}{lcccccc} 
Absent & 19 & 63.3 & 12 & 40.0 & 31 & \\
Acute (A) & 7 & 23.3 & 6 & 20.0 & 13 & 0.059 \\
$\begin{array}{l}\text { Chronic } \\
\text { (B) }\end{array}$ & 4 & 13.3 & 12 & 40.0 & 16 & \\
\\
\multicolumn{2}{l}{ Pneumonitis } \\
Yes & 5 & 16.7 & 11 & 36.7 & 16 & \\
No & 25 & 83.3 & 19 & 63.3 & 44 & 0.080
\end{tabular}

\section{Macroscopy}

\begin{tabular}{ccccccc} 
Grade 0 & 27 & 90.0 & 8 & 26.7 & 35 & \\
Grade 1 & 1 & 3.3 & 9 & 30.0 & 10 & \\
Grade 2 & 0 & 0.0 & 3 & 10.0 & 3 & 0.000 \\
Grade 3 & 0 & 0.0 & 2 & 6.7 & 2 & \\
Grade 4 & 2 & 6.7 & 8 & 26.7 & 10 & \\
Total & 30 & 100.0 & 30 & 100.0 & 60 & \\
\hline Chi-square test. & & & & & &
\end{tabular}

TABLE 2 - Comparison of variable grades of reaction, type of reaction and macroscopy by group Mann-Whitney.

\begin{tabular}{cccccc}
\hline Variable & Group & $\mathrm{n}$ & Mean rank & Median & $\mathrm{p}$ \\
\hline $\begin{array}{c}\text { Grade of } \\
\text { reaction }\end{array}$ & Control & 30 & 26.5 & Grade 0 & 0.042 \\
& Babassu & 30 & 34.6 & Grade 1 & \\
& & & & & \\
$\begin{array}{c}\text { Type of reac- } \\
\text { tion }\end{array}$ & Control & 30 & 26.0 & Absent & \\
& Babassu & 30 & 35.0 & $\begin{array}{c}\text { Acute } \\
\text { (A) }\end{array}$ & 0.029 \\
& & & & & \\
Macroscopy & Control & 30 & 21.3 & Grade 0 & 0.0001 \\
& Babassu & 30 & 39.8 & Grade 1 & \\
\hline
\end{tabular}

At $48 \mathrm{~h}$ and $72 \mathrm{~h}$ post-intervention, a significant favorable effect $(p<0.05)$ of babassu was seen only on the macroscopic analysis; by contrast, at the $21^{\circ}$ day post-intervention a significant damaging effect of babassu $(p<0.05)$ was evidenced by the three variables (Tables 3 and 4).

TABLE 3 - Comparison of variable grades of reaction, type of reaction and macroscopy by group at each timepoint using Mann-Whitney test.

\begin{tabular}{cccccc}
\hline $\begin{array}{c}\text { Time- } \\
\text { point }\end{array}$ & Variable & Group & $\begin{array}{c}\text { Mean } \\
\text { rank }\end{array}$ & Median & p \\
\hline & $\begin{array}{c}\text { Grade of } \\
\text { reaction }\end{array}$ & Control & 26.5 & Grade 0/1 & 0.830 \\
& & & 34.6 & Grade 0 &
\end{tabular}

$48 \mathrm{~h} \quad \begin{array}{rcccc}\text { Type of } & \text { Control } & 26.0 & \text { Absent/ } & \\ \text { reaction } & \text { Acute (A) } & 0.702 \\ & & \text { Babassu } & 35.0 & \text { Absent }\end{array}$

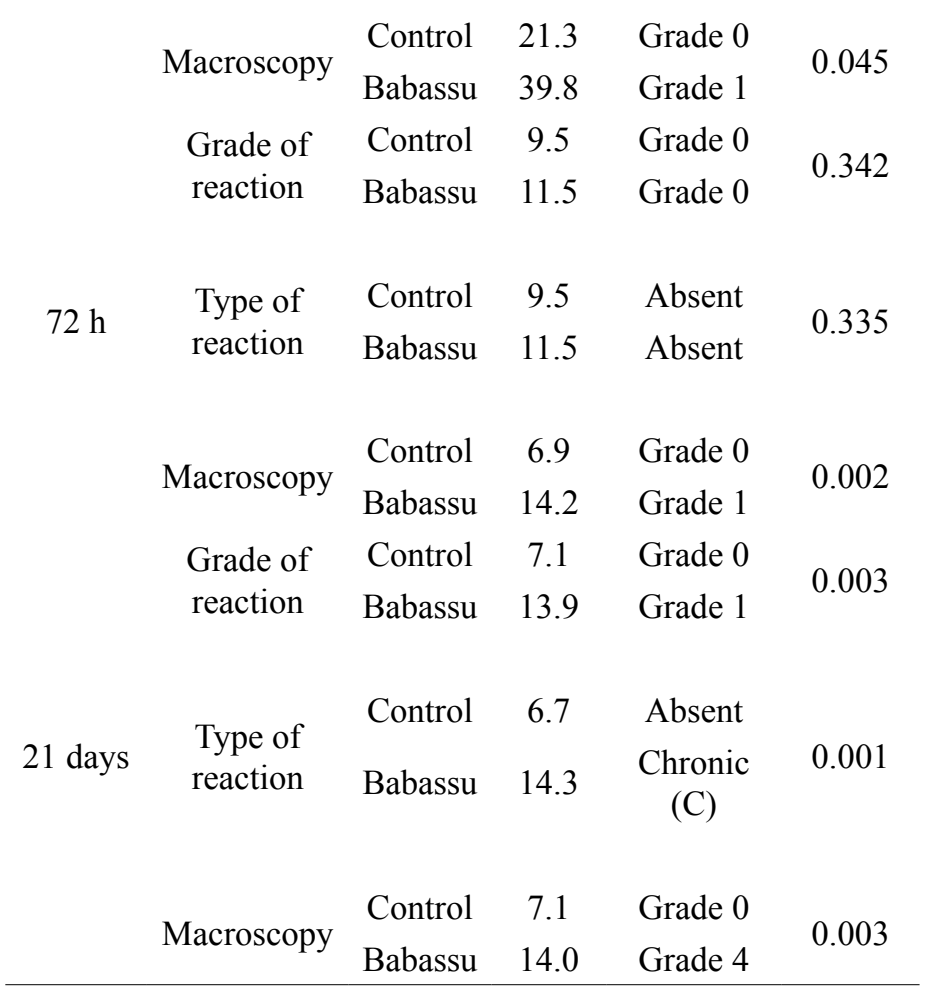


TABLE 4 - Comparison of variable grades of reaction, type of reaction and macroscopy for timepoint within each group using Kruskal-Wallis test.

\begin{tabular}{|c|c|c|c|c|c|}
\hline Timepoint & Variable & Timepoint & $\begin{array}{c}\text { Mean } \\
\text { rank }\end{array}$ & Median & $\mathrm{p}$ \\
\hline \multirow{9}{*}{ Control } & \multirow{3}{*}{$\begin{array}{l}\text { Grade of } \\
\text { reaction }\end{array}$} & $48 \mathrm{~h}$ & 17.5 & Grade $0 / 1$ & \multirow{3}{*}{0.379} \\
\hline & & $72 \mathrm{~h}$ & 13.0 & Grade 0 & \\
\hline & & 21 days & 16.0 & Grade 0 & \\
\hline & \multirow{3}{*}{$\begin{array}{l}\text { Type of } \\
\text { reaction }\end{array}$} & $48 \mathrm{~h}$ & 17.1 & $\begin{array}{c}\text { Absent/ } \\
\text { Acute (A) }\end{array}$ & \multirow{3}{*}{0.470} \\
\hline & & $72 \mathrm{~h}$ & 13.2 & Absent & \\
\hline & & 21 days & 16.3 & Absent & \\
\hline & \multirow{3}{*}{$\begin{array}{c}\text { Macros- } \\
\text { copy }\end{array}$} & $48 \mathrm{~h}$ & 15.6 & Grade 0 & \multirow{3}{*}{0.996} \\
\hline & & $72 \mathrm{~h}$ & 15.4 & Grade 0 & \\
\hline & & 21 days & 15.6 & Grade 0 & \\
\hline \multirow{9}{*}{ Babassu } & \multirow{3}{*}{$\begin{array}{l}\text { Grade of } \\
\text { reaction }\end{array}$} & $48 \mathrm{~h}$ & $\begin{array}{c}12.8 \\
\mathbf{b}\end{array}$ & Grade 0 & \multirow{3}{*}{0.008} \\
\hline & & $72 \mathrm{~h}$ & $11.9^{\mathrm{b}}$ & Grade 0 & \\
\hline & & 21 days & $21.8^{a}$ & Grade 1 & \\
\hline & \multirow{3}{*}{$\begin{array}{l}\text { Type of } \\
\text { reaction }\end{array}$} & $48 \mathrm{~h}$ & $11.0^{\mathrm{b}}$ & Absent & \multirow{3}{*}{0.001} \\
\hline & & $72 \mathrm{~h}$ & $11.9^{\mathrm{b}}$ & Absent & \\
\hline & & 21 days & $23.6^{\mathrm{a}}$ & $\begin{array}{l}\text { Chronic } \\
\text { (C) }\end{array}$ & \\
\hline & \multirow{3}{*}{$\begin{array}{c}\text { Macros- } \\
\text { copy }\end{array}$} & $48 \mathrm{~h}$ & $11.6^{\mathrm{b}}$ & Grade 1 & \multirow{3}{*}{0.019} \\
\hline & & $72 \mathrm{~h}$ & $\begin{array}{c}13.4 \\
\text { b }\end{array}$ & Grade 1 & \\
\hline & & 21 days & $21.6^{\mathrm{a}}$ & Grade 4 & \\
\hline
\end{tabular}

a,b Different letters indicate $\mathrm{p}<0.05$ on the Student-Newman-Keuls test.

\section{Discussion}

This is the first report describing an experimental pleurodesis model.

In the present study, a natural substance known popularly and scientifically for its anti-inflammatory and healing actions was used. Factors influencing the decision to use babassu were its ease obtainment, applicability to animals, low cost and the refining experience of the university staff ${ }^{9,12,14}$.

In this study, the aqueous extract of Orbignya phalerata, at the dose administered, promoted no adverse reactions like other drugs in literature. Godazandeh et al. ${ }^{11}$, when using povidoneiodine, noted dyspnea, cough and chest pain, symptoms not observed in the use of babassu.
No previous experimental studies administering Orbignya phalerata to rat pleura were found in the related literature. Babassu is a plant of the palmae family native to the mid-north of Brazil and found predominantly in the state of Maranhão ${ }^{25}$.

Previous studies on the healing of the stomach and bladder after intraperitonial use of aqueous extract of the substance showed an enhancing action in macro and microscopic healing ${ }^{14}$.

To prove efficiency, semiquantitative scoring methods are widely used for obtaining histological information in biomedical research. These methods are employed in experimental studies on animals. Klopfleisch ${ }^{18}$ in a systematic review of semiquantitative score systems and multiparameters for histopathological evaluation of various organs and tissues in rats, reinforced the validity of this methodology and cited several articles, employing the 0-3 rating scale for several parameters, including assessment of inflammatory response in lung tissue. With regard to the "quality/type of inflammation", this was classified as "acute" or "chronic" based on the predominant cell type in the inflammatory infiltrate or tissue samples. Tissues with a predominance of polymorphonuclear leukocytes (neutrophils) were categorized as "acute inflammation" whereas samples with predominance of leukocyte/mononuclear cells (lymphocytes, plasma cells and macrophages) were categorized as "chronic inflammation". This stratification is based on the concepts of classic inflammatory reaction mechanisms, as described by Robbins et al. ${ }^{19}$.

Based on the paper published by Batista et al. ${ }^{26}$, with babassu in the stomach of rats, the peritoneum and the pleura seemed similar and thus may have the same effect on the formation of adhesions.

The variable grades of reaction, type of reaction and pneumonitis showed no significant difference $(p>0.05)$ between groups, whereas a difference was found on macroscopic analysis with $73.3 \%$ of the babassu group exhibiting some degree of macroscopic change and the control group showing no changes ${ }^{22}$.

For the groups at two and three days, only a weak action was observed in the experimental group - much lower than that seen at 21 days -, where this was attributed to short period of use of the substance; however, in the experimental and control groups at 21 days, moderate inflammatory changes were evident. Overall, there was a significant favorable effect of babassu on the variable grades of reaction, type of reaction and on macroscopic analysis. Compared to Teixeira et al..$^{23}$ results, babassu extract showed no significant difference.

The findings of babassu action on the pleural cavity differ to other substances in which the majority of rats exhibited 
slight adhesions, as well as acute and mild inflammatory changes macroscopically at study endpoint ${ }^{24}$.

There are many studies in the literature reporting the successful use of a variety of substances in pleurodesis s.23,26. $^{2}$. However, substances such as talc, povidone, OK-432 and cytokine, are already in medical use, but no studies are available with phytotherapics, in this case with the use of Orbignya phalerata (babassu) or other plants from Brazilian flora.

\section{Conclusion}

The aqueous extract of babassu (Orbignya phalerata) was highly irritating to the pleura and pulmonary parenchyma of rats, evidenced macroscopically by numerous adhesions, while no major changes were evident microscopically

\section{References}

1. Peek H, van der Brugger W, Limonard G. Pleural FDG uptake more than a decade after talc pleurodesis. Case Rep Med. 2009;2009:650864. doi: 10.1155/2009/650864.

2. Lee Pyng. Point: should thoracoscopic talc pleurodesis be the first choice management for malignant effusion? Yes. Chest. 2012 Jul;142(1):15-7. doi: 10.1378/12-1085.

3. Silva CE, Santos OJ, Ribas-Filho JM, Tabushi FI, Kume MH, Jukonis LB, Cella IF. Effect of Carapa guianensis Aublet (Andiroba) and Orbignya phalerata (Babassu) in colonic healing in rats. Rev Col Bras Cir. 2015 Dec;42(6):399-406. doi: 10.1590/010069912015006009.

4. Araújo LA, Mrué F, Neves RA, Alves MM, Silva-Júnior NJ, Silva MS, Melo-Reis PR. Effects of topical treatment with Euphorbia tirucalli latex on the survival and intestinal adhesions in rats with experimental peritonitis. Arq Bras Cir Dig. 2015 Dec;28(4):243-6. doi: 10.1590/S0102-6720201500040006.

5. Hashemzadeh S, Hashemzadeh K, Mamaghani K, Ansari E, Aligholipour R, Golzari SEJ, Ghabili K. Pleurodesis by erythromycin, tetracycline, AerosilTM 200, and erythromycin plus AerosilTM 200 in a rat model: a preliminary study. Daru. 2012 Nov;20(1):79. doi: 10.1186/2008-2231-20-79.

6. Gözübüyük A, Özpolat B, Çiçek A F, Çaylak H, Yücel O, Kavakli K, Gürkök S, Genç O. Comparison of side effects of oxytetracycline and talc pleurodesis: an experimental study. J Cardiotorac Surg. 2010 Dez;(5):1-6. doi: 10.1186/1749-8090-5-128.

7. Yasojima EY, Teixeira RK, Houat Ade P, Costa FL, Yamaki VN, Feitosa-Junior DJ, Silva CA, Brito MV. Copaiba oil influences ventral hernia repair with Vicryl ${ }^{\circledR}$ mesh? Arq Bras Cir Dig. 2015 Jul-Sep;28(3):186-9. doi: 10.1590/S0102-67202015000300010.

8. Castilho TJ, Campos AC, Mello EV. Effect of omega-3 fatty acid in the healing process of colonic anastomosis in rats. Arq Bras Cir Dig. 2015 Dec;28(4):258-61. doi: 10.1590/S0102-6720201500040010.

9. Inoue $\mathrm{T}$, Ishida $\mathrm{A}$, Nakamura $\mathrm{M}$, Nishine $\mathrm{H}$, Mineshita $\mathrm{M}$, Miyazawa T. Talc pleurodesis for the management of malignant pleural effusions in Japan. Intern Med. 2013 Jan;(52):1173-6. doi: 10.2169/52.9281.

10. Menna C, Andreetti C, Ibrahim M, Maurizi G, Poggi C, Barile R, Cassiano F, Rendina E A. The effects of silver nitrate pleurodesis after a failed thoracoscopic talc poudrage. Biomed Res Int. 2013;2013:295890. doi: 10.1155/2013/295890.

11. Godazandeh G, Qasemi NH, Saghafi M, Mortaziam M, Tayebi P. Pleurodesis with povidone-iodine, as an affective procedure in management of patients with malignant pleural effusion. J Thorac Dis. 2013;5(2)141-4. doi: 10.3978/j.issn2072-1439.2013.02.02.

12. Saito EH, Nunes RA, Higa C. Pleurodese. Pulmão RJ. 2006;15(2):110-6.

13. Silva BP, Parente JP. An anti-inflammatory and immunomodulatory polysaccharide from Orbignya phalerata. Fitoterapia. 2001;(72):88793. doi: 10.1016/S0367-326X(01)00338-0.

14. Batista CP, Torres OJM, Matias JEF, Moreira ATR. Efeito do extrato aquoso de Orbignya Phalerata (babaçu) na cicatrização do estômago em ratos: estudo morfológico e tensiométrico. Acta Cir Bras. 2006;21 Suppl 3:26-32. doi: 10.1590/S0102-86502006000900005.

15. Martins NLP, Malafaia O, Ribas-Filho JM. Análise comparativa da cicatrização da pele com o uso intraperitoneal de extrato aquoso de Orbignya Phalerata (babaçu). Estudo controlado em ratos. Acta Cir Bras. 2006;21 Suppl 3:66-75. doi: 10.1590/S010286502006000900010 .

16. Brito-Filho SB, Martins JEF, Stahlke Junior HJ, Torres OJM. Análise da cicatrização na linha Alba com uso de extrato aquoso de Orbignya Phalerata (babaçu). Estudo controlado em ratos. Acta Cir Bras. 2006;21 Suppl 3:76-88. doi: 10.1590/S0102-86502006000900011.

17. Westphal FL, Lima LC. Guimarães RA, Souza RFS DE, Couto SB, Nakajima SR. Avaliação das alterações pleuropulmorares com injeção de óleo de resina de copaíba, extrato aquoso de crajiru e polivinilpirrolidona iodado (PVPI) na pleura e parênquima pulmonar de ratos. Rev Col Bras Cir. 2007;34(3):170-5. doi: 10.1590/S010069912007000300007.

18. Robert K. Multiparametric and semiquantitative scoring systems for the evaluation of mouse model histopathology - a systematic review. BMC Vet Res. 2013 Jun;9:123. doi: 10.1186/1746-6148-9-123.

19. Robbins \& Cotran Pathologic Basis of Disease. Kumar, Abbas, and Aster. Saunders Elsevier, Professional Edition, 2015.

20. Tonietto T, Pila ES, Madke GR, Lima e Silva U, Pelicetti JC, Camargo JJ, Cardoso MR, Nonning RB, Cardoso PF. Empiema pleural experimental ratos: avaliação dos efeitos do uso intrapleural de dextran-40 na fase fibrinopurulenta. J Pneumol. 1999;25(3):14752. doi: 10.1590/S0021-75572001000600009.

21. Rego TJA. Fitogeografia das plantas medicinais no Maranhão. São Luís: EDUFMA; 1993.

22. Santos OJ, Carvalho-Júnior FF, Sauaia-Filho EN, Santos RHP, SantosRAP, Barbalho WG. Cicatrização gástrica com uso do extrato da Euphorbia Tirucalli L.: estudo em ratos. Arq Bras Cir Dig. 2013;26(4):256-9. doi: 10.1590/S0102-67202013000400002.

23. Srour N, Amjadi K, Forster AJ, Aaron SD. Management of malignant pleural effusions with indwelling pleural catheters or talc pleurodesis. Can Respir J. 2013 Mar-Apr;20(2):106-10. PMID: 23616967.

24. Teixeira LR, Vargas FS, Puka J, Acencio MMP, Antonangelo L, Terra RM, Damico FM, Pitta FG, Marchi E. Effectiveness and safety of iodopovidone in an experimental pleurodesis model. Clinics. 2013;68(4):557-62. doi: 10.6061/2013(04)19.

25. Nikbakhsh N, Amiri AP, Hoseinzadeh D. Bleomycin in the treatment of 50 cases with malignant pleural effusion. Caspian J Intern Med. 2011 Jun; 2(3):274-8. PMID: 24049586.

26. Ferreira EC, Matias JEF, Campos ACL, Tâmbara Filho R, Rocha LCA, Timi JRR, Sado HN, Sakamoto DG, Tolazzi ARD, Soares Filho MP. Análise da cicatrização da bexiga com extrato aquoso da Orbignya phalerata (BABAÇU). Estudo controlado em ratos. Acta Cir Bras. 2006 Jun;21Supl 3:33-9. doi: 10.1002/hep.26599. 
27. Kim JE, Lee C, Park KI, Park MS, Namgung R, Park IK. Successful pleurodesis with OK-432 in preterm infants with persistent pleural effusion. Korean J Pediatr. 2012;55(5):177-80. doi: 10.3345/ kjp.2012.55.5.177.

\section{Correspondence:}

Elias Amorim

Departamento de Cirurgia, UFMA

Avenida dos Portugueses, 1966

65080-805 São Luís-MA Brasil

amorimelm@gmail.com

Received: Dec 18, 2015

Review: Feb 20, 2016

Accepted: Mar 22, 2016

Conflict of interest: none

Financial source: none

${ }^{1}$ Research performed at Department of Surgery, Universidade Federal do Maranhão (UFMA), and Santa Casa de Misericórdia de São Paulo, Brazil. Part of Postdoctoral thesis, Postgraduate Program in Research in Surgery, Faculdade de Ciências Médicas da Santa Casa de São Paulo. Tutor: Roberto Saad Junior. 